\title{
Stress-strain state of seepage-control wall constructed for repairs of earth rock-fill dam
}

\author{
Напряженно-деформированное состояние \\ противофильтрационной стены, выполненной для ремонта \\ каменно-земляной плотины
}

\author{
M.P. Sainov, \\ O.V. Anisimov, \\ National Research Moscow State Civil Engineering \\ University, Moscow, Russia
}

\author{
Канд. техн. наук, доцент М.П. Саинов, \\ аспирант О.В. Анисимов, \\ Национальный исследовательский \\ Московский государственный строительный \\ университет, г. Москва, Россия
}

Key words: earth-rockfill dam; cut-off wall; dam failure; soil subsidence; stress-strain state; claycement concrete; seepage load; bored piles

\begin{abstract}
Ключевые слова: каменно-земляная плотина; стена в грунте; авария плотины; просадки грунта; напряжённо-деформированное состояние; глиноцементобетон; фильтрационная нагрузка; буронабивные сваи
\end{abstract}

\begin{abstract}
Methodology and the results of numerical modeling of stress-strain state (SSS) of an earth-rockfill dam are considered, where after a failure of the clay core there was created a new seepagecontrol element presented by a clay-cement concrete wall. Calculations were conducted on the example of the dam section of Kureyka HPP, where emergency situation occurred in 1992. For repairs of the 25 high dam in the core and in the foundation there was arranged a $35 \mathrm{~m}$ deep wall made of bored piles. SSS analyses of the dam were conducted with use of the computer program elaborated by the author. This permitted consideration in the analyses of a number of important factors such as the sequence of the dam and the wall construction, non-linearity of soils deformation, their subsidence as well as timedependent variation of seepage forces. Seepage calculations showed that load on the piles from seepage flow is formed over a long time due to the durable process of the wall construction. If piles are arranged sequentially, one pile after another, during this time clay-cement concrete acquires about $50 \%$ of design strength. If the wall is constructed in 2 stages, clay-cement concrete acquires about $80 \%$ of its strength. SSS analyses showed that the wall in the failed dam performs in complicated conditions: due to a non-uniform structure of soil mass, it is subject to complicated bending deformations. To avoid the appearance of tensile stresses in the wall it is recommended to make the wall of plastic clay-cement concrete whose deformation is close to deformation of soils.
\end{abstract}

Аннотация. Рассматриваются методика и результаты численного моделирования напряжённо-деформированного состояния (НДС) каменно-земляной плотины, в которой после выхода из строя её глинистого ядра устроен новый противофильтрационный элемент - стена из глиноцементобетона. Расчёты проводились на примере участка плотины Курейской ГЭС, аварийная ситуация на котором произошла в 1992 году. Для ремонта плотины высотой 25 м в ядре и основании была устроена стена глубиной 35 м из буронабивных свай. Исследования НДС плотины проводились с помощью вычислительной программы, составленной автором. Это позволило учесть в расчётах ряд важных факторов, таких как последовательность возведения плотины и стены, нелинейность деформирования грунтов, их просадки, а также изменение во времени фильтрационных сил. Фильтрационные расчёты показали, что нагрузка на сваи от фильтрационного потока формируется длительное время из-за продолжительного технологического процесса возведения стены. Если сваи устраиваются последовательно, свая за сваей, то за это время глиноцементобетон успеет набрать около 50 \% проектной прочности. Если стена возводится в 2 очереди, то глиноцементобетон набирает уже около 80 \% своей прочности. Расчёты НДС показали, что стена в аварийной плотине работает в непростых условиях - из-за неоднородного строения грунтового массива она испытывает сложные изгибные деформации. Во

Саинов М.П., Анисимов О.В. Напряженно-деформированное состояние противофильтрационной стены, выполненной для ремонта каменно-земляной плотины // Инженерно-строительный журнал. 2016. № 8(68). C. $3-17$. 
избежание появления в стене растягивающих напряжений рекомендуется выполнять стену из пластичного глиноцементобетона, деформируемость которого близка к деформируемости грунтов.

\section{Introduction}

Structures like the "cutoff wall" started to be used as seepage control curtains in the middle of the $\mathrm{XX}$-th century. Recently seepage control arrangements of this type were broadly used for seepage control in the dam foundation. The examples may be Yumaguza [1], Gotsatlin (Russia) and Sangtuga (Tajikistan) [2] dams, dams Karkheh (Iran) [3], Peribonka (Canada) [4], Merowe (Sudan) [5], Dhauliganga (India) [7] and others [6, 8, 9]. Seepage-control walls were also arranged as diaphragms of earthfill dams [10].

One more important use of structures like "slurry trench cutoff wall" was their application for repairs of earthfill dams. For example, a $70 \mathrm{~m}$ deep wall was arranged in the foundation of Sylvenstein dam during its reconstruction [11].

At repairs of earthfill dams, the arrangement of a new seepage-control element sometimes is required not in the dam foundation but inside the dam. The thing is that at a number of earth rock-fill dams there have occurred emergency situations when the seepage-control element failed. The examples may be dams Balderhead (Great Britain) [12], Hyttejuvet (Canada) [13], Kolyma and Kureyka [14] dams (Russia). Through joints were formed in clay cores of these dams which became paths of intensive seepage. This seepage resulted in intensive scour by seepage flow of the dam body and soil removal beyond the dam profile. Further development of seepage deformations may result in full dam failure unless emergency and repair measures have been taken.

Heavy overhaul of damaged earth rock-fill dams may be carried out using two main methods. The first one envisages repairs of soil seepage-control element by filling joints developed in it with different mortars. The second, more reliable method suggests arrangement in the dam body of a new seepagecontrol element. Such seepage-control element is usually presented by seepage-control walls constructed by a "cutoff wall" method. The first seepage-control wall was arranged in 1968 for repairs of Balderhead dam [12].

A new seepage-control element has to work in complicated conditions because the density of the enclosing it soil was disturbed during failure. This article deals with studies of operation conditions of the seepage-control wall arranged in the body of the failed earth rock-fill dam as well as the effect of these conditions on the wall safety.

The study was conducted on the example of Kureyka HPP dam. Kureyka HPP earth rock-fill dam was constructed in 1980-s on the Kureyka River in Russia's Far North [14].

The emergency situation at Kureyka dam occurred on July 26, 1992, at its left-bank section. During failure the upstream level was $95 \mathrm{~m}, 0.5 \mathrm{~m}$ higher than FSL. The length of the emergency section was about $30 \mathrm{~m}$ (from Sta. 7+00 to Sta. 7+32). The emergency situation was created due to the sharp increase of seepage discharge (from 20 to $1750 \mathrm{l} / \mathrm{s}$ ), removal by seepage flow of a considerable volume of soil, as well as subsidence of the dam upstream slope crest. Crest subsidence at the dam emergency section amounted to about $1 \mathrm{~m}[14,15]$.

As a mitigation measure the clay soil was filled in the upstream slope and at the downstream slope, a stone drain was arranged with surcharging by gravel-pebble soil.

By the flood period of 1993 the repairs on the dam had been fulfilled, which consisted of injection of cement-clay mortars [16]. At drilling operations, disturbances in core integrity were revealed. There were observed sections with liquid loam as well as sections filled with sand and gravel. Three water permeable zones were found in the structure, which created through seepage paths (Fig. 1). Two zones were located in the dam core: the upper zone was approximately in the middle of the core height $(\nabla 81 \div 83 \mathrm{~m})$, the lower zone was at its toe $(\nabla 76 \div 80 \mathrm{~m})$. The third permeable zone does not cross the core. The beginning of this zone was located vertically and separated the core from the upstream apron. Through this joint water ingressed in the foundation sand interlayer under the core and through it bypassed the seepage-control element of the dam. Evidently, development of the emergency situation started from this particular zone, and located above water permeable zones were formed later as a result of the emergency situation development. 


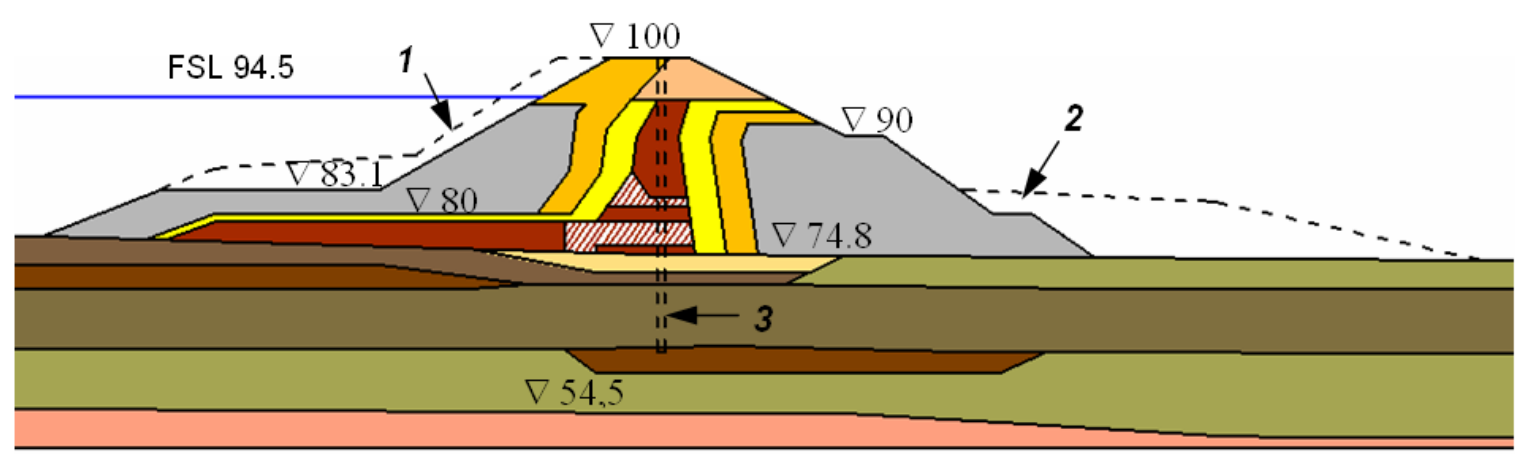

Figure 1. Dam configuration in the design section (Sta. 7+27)

1 - profile of fill on the upstream slope for emergency situation liquidation; 2 - profile of fill on the downstream slope; 3 - location of the seepage-control wall made for dam repairs

Color designations of the dam body and foundation materials:

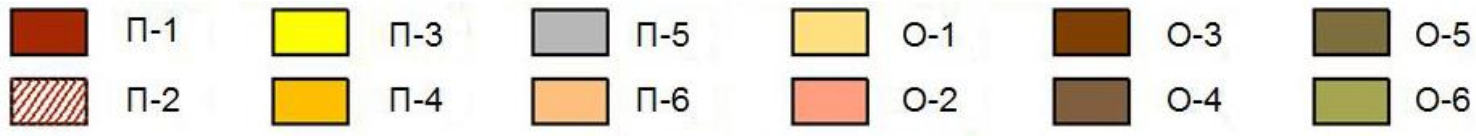

ח-1 - loam of the core and the apron in the intact state; $\Pi-2$ - disturbed zone in the dam core;

ח-3 - soil of the first layer of transition zones; ח-4 - soil of the second layer of transition zones;

ח-5 - rock muck of the dam shells; $\Pi-6$ - gravel-pebble soil on the dam crest;

0-1 - foundation sand; 0-2 - rock foundation; 0-3 - foundation loam;

0-4 - foundation sandy loam; 0-5 - foundation gravel-pebble soil with loam filler;

0-6 - foundation gravel-pebble soil with sandy loam filler

Considerable damage of the dam core and foundation made their rehabilitation impossible without the reservoir drawdown, therefore, it was decided to make repairs by arranging a new non-soil seepagecontrol element.

The design of measures on repairs of the dam emergency section envisaged construction of a wall at the section from Sta. $6+20$ to Sta. $7+60$. The wall was made of bored piles $1200 \mathrm{~mm}$ in diameter with spacing $850 \mathrm{~mm}[17,18]$. The design depth of the wall is $35 \mathrm{~m}$. It cuts the about $25 \mathrm{~m}$ high earthfill dam body and deepens into the earth foundation for about $10 \mathrm{~m}$.

For the seepage-control wall material there was used liquid plastic clay-cement concrete consisting of $125-156 \mathrm{~kg}$ of Portland cement and $120-140 \mathrm{~kg}$ of bentonite, $380-680 \mathrm{~kg}$ of sand and $900-1000 \mathrm{~kg}$ of gravel $[18,19]$. The density of this material is $1.98-2.26 \mathrm{~kg} / \mathrm{m}^{3}$. This clay-cement concrete has a cube uniaxial compression strength 1-2 MPa. However, its strength properties are rather unstable, and the process of gaining strength is rather durable (Table 1) [18, 19]. Over the first 7 days is gains approximately $50 \%$ of strength at the age of 28 days. The maturing process also continues after 28 days.

Table 1. Compressive strength of clay-cement concrete samples

\begin{tabular}{|c|c|c|c|}
\hline Age of samples & $\mathbf{7}$ days & 28 days & 90 days \\
\hline Strength minimum value, $\mathrm{MPa}$ & 0.42 & 0.57 & 0.70 \\
\hline Strength average value, $\mathrm{MPa}$ & 0.91 & 1.36 & 2.02 \\
\hline Strength maximum value, $\mathrm{MPa}$ & 1.52 & 2.38 & 3.07 \\
\hline
\end{tabular}

There is controversial information about deformability of clay-cement concrete. According to the data [18] the deformation modulus of clay-cement concrete is equal to 10-20 MPa, and according to the data [19] it is $30-200 \mathrm{MPa}$.

The wall was constructed in 1998-2000 and to date it has been working reliably. Our studies of Kureyka dam seepage-control wall workability should determine the degree of safety of this structure and reveal its determining factors.

Саинов М.П., Анисимов О.В. Напряженно-деформированное состояние противофильтрационной стены, выполненной для ремонта каменно-земляной плотины // Инженерно-строительный журнал. 2016. № 8(68). C. 3-17. 


\section{Methods \\ Peculiar features of design studies methodology}

Solution of the given assignment is rather complicated because SSS analysis should consider the complicated design scheme of the structure behavior: multiple important factors affecting its SSS.

The first factor is construction sequence of the structure and the wall itself. The seepage-control wall is constructed in the already existing earthfill dam, therefore, before solving the task about the dam behavior with the wall it is necessary to solve the problem of the dam SSS before construction of the wall. Besides, it is necessary to represent the process diagram of the wall construction. The methodology of the wall construction of bored piles envisages filling of piles with clay-cement concrete. Hardening of clay-cement concrete occurs already in the structure. Therefore, calculation should be carried out at least in two stages. The first stage refers to clay-cement concrete in non-hardened semi-liquid state. At this stage the wall SSS from its own dead weight is formed. At that, it is necessary to take into account that clay-cement concrete may freely settle under its own weight, because its shear strength is small. For this purpose in the design diagram it is necessary to envisage presence of a sliding contact between claycement concrete and soil. If this feature is not taken into account the wall stress state may be distorted due to the effect of clay-cement concrete "hanging" on the surrounding soil. The second stage of analysis is the behavior of wall of hardened clay-cement concrete. Perception by the wall of seepage forces may occur both on the first and the second stages depending on conditions of these forces formation.

The second factor is the value and conditions of formation of external forces acting on the wall and the whole structure. As loads on the seepage-control wall are formed by seepage flow in order to determine these loads it is necessary first to solve the problem of the structure seepage regime.

Before failure the dam core may be considered to be watertight, therefore, action of water corresponds to hydrostatic pressure. During failure, water permeable zones are formed; therefore, hydrostatic pressure in them should be replaced by seepage forces. For determining seepage forces it was necessary to solve the problem of seepage through water permeable zones. The obtained distribution of seepage flow levels is shown in Figure 2. Forces from seepage flow are distributed forces. Inside water permeable zones the seepage forces are distributed by volume. At water permeable boundaries of these zones the seepage forces are presented by surface forces from pressure of filtering water.

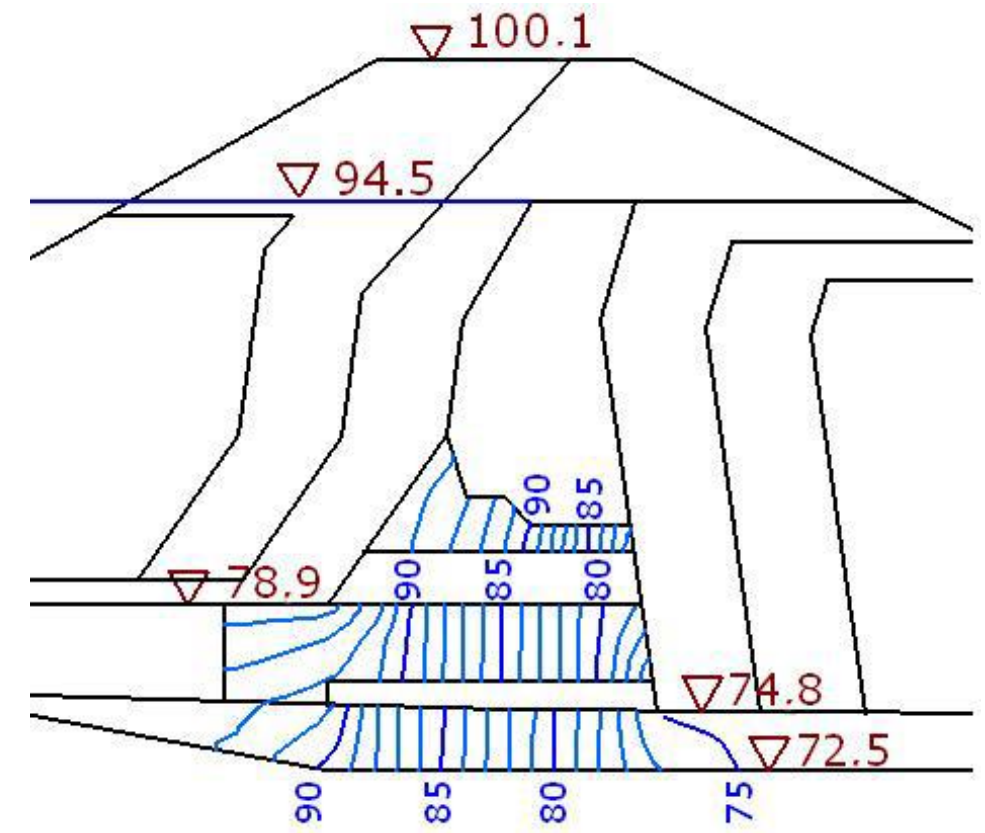

Figure 2. Location of lines of the equal level in water permeable zones of the structure during failure

Arrangement of the seepage-control wall in the dam cardinally changes the seepage pattern: seepage head is concentrated on the wall. However, variation of seepage flow occurs slowly, gradually. Therefore, conditions of the wall perception of seepage load depend on how fast this load will rise as compared to the process of clay-cement concrete maturing.

Sainov M.P., Anisimov O.V. Stress-strain state of seepage-control wall constructed for repairs of earth rock-fill dam. Magazine of Civil Engineering. 2016. No. 8. Pp. 3-17. doi: 10.5862/MCE.68.1 
In order to determine the character of seepage load formation it is necessary to solve a $3 \mathrm{D}$ problem on unsteady seepage regime of the structure during construction of a watertight wall in it. This problem was solved by M.P. Sainov in his Ph. D. thesis. Studies showed that the value of seepage load on the pile depends on location of this pile within the wall. Seepage load on end piles is small because seepage flow bypasses the wall. The longer is the distance of the pile from the end of the wall the higher is seepage pressure which it perceives.

Investigations showed that formation of seepage load on the wall occurs rather quickly. Seepage pressure manages to acquire values typical for steady seepage regime due to low rate of the wall construction: 1-2 piles a day.

However, it should be taken into account that formation of seepage load starts from the moment when the wall becomes an entire barrier. Depending on the wall construction sequence the character of increase of seepage load on one bored pile may be different. As it is known in practice there may be used two sequences of construction of a bored piled wall: the first one when piles are arranged sequentially and the second when the wall is constructed in two stages (first-stage piles are arranged next but one, and then the second-stage piles fill the space between the first-stage piles).

Figure 3 shows time-dependent variation of water levels around one separate pile for two construction methods of the wall ${ }^{1}$. Water level from the pile upstream side rises, while from the downstream side it lowers.

When piles are arranged subsequently, the rate of seepage forces increase is determined by the rate of bored piles construction. At placement of one pile a day the pressure on the wall will increase faster than the rate of clay-cement concrete hardening (Fig. 3). When piles are arranged in 2 stages there appears the difference between operation conditions of the first-stage piles and the second-stage piles. The first-stage piles for durable time do not have loads from seepage flow, because it passes between them. Seepage pressure arises only when space between piles of the first stage is filled by the secondstage piles. During these several days clay-cement concrete may acquire $50-80 \%$ of its strength. From the moment of the wall closure the pressure on piles of the first and the second stages starts to grow intensively (Fig. 3). This process is faster than that during subsequent construction.

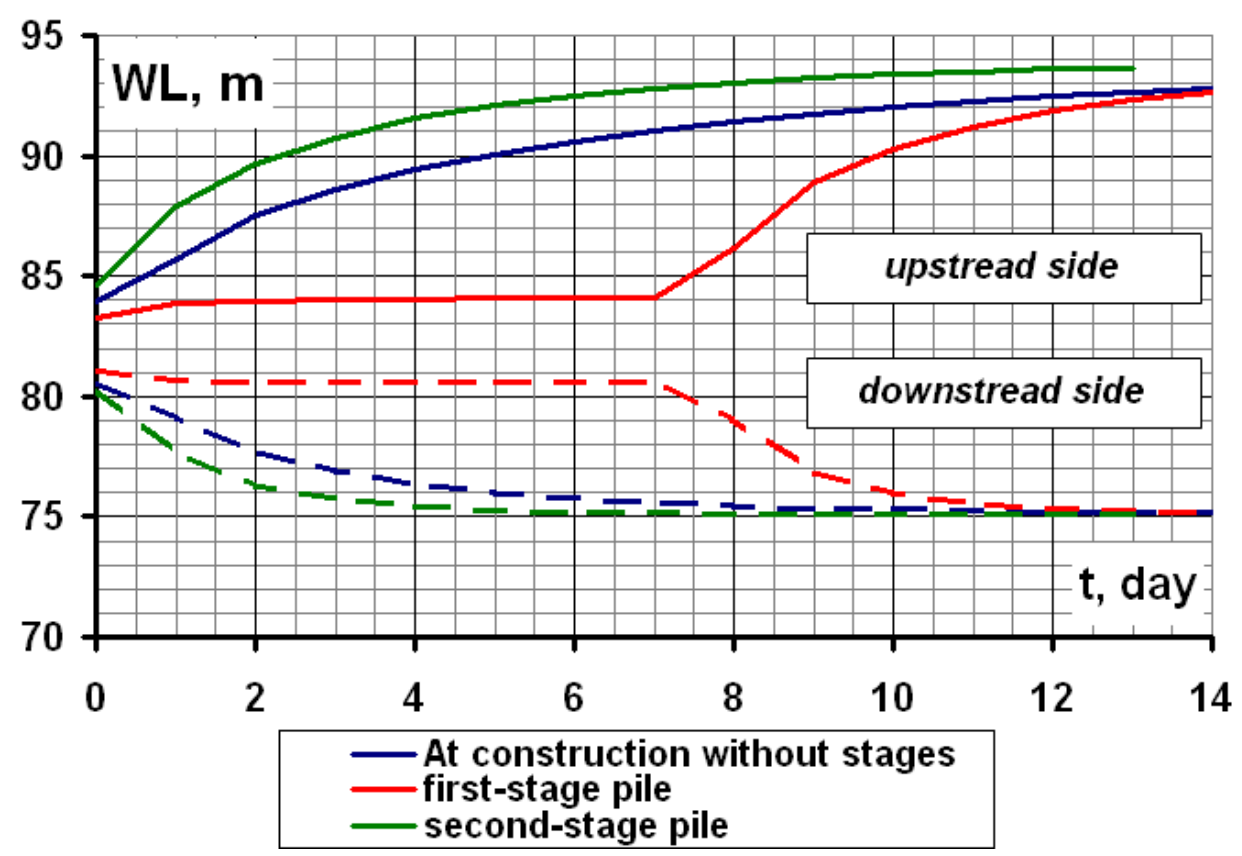

Figure 3. Variation of seepage water levels around a pile

Thus, the first-stage piles will perceive external forces at nearly hardened clay-cement concrete, but the second-stage piles at non-hardened clay-cement concrete. From the point of view of the stress state formation the first-stage piles are in worse conditions because at greater stiffness of material the greater stresses occur. The most dangerous case may be taken into account when seepage load is taken by a pile at hardened clay-cement concrete.

\footnotetext{
${ }^{1}$ At wall construction in 2 stages it was assumed that at each stage 7 pilles are placed.

Саинов М.П., Анисимов О.В. Напряженно-деформированное состояние противофильтрационной стены, выполненной для ремонта каменно-земляной плотины // Инженерно-строительный журнал. 2016. № 8(68). C. $3-17$.
} 
The third factor is conditions of perceiving external forces by the dam and foundation. The peculiarity of considered problem is the fact that the seepage-control wall is constructed in the already operating dam. Even before the wall construction the dam already took loads from seepage flow, therefore, with wall arrangement the loads are redistributed, but new ones do not appear. Water pressure on the wall appears, but pressure on the core upstream face disappears.

This peculiarity is important from the point of view of an earthfill structure behavior. Soils have a pronounced non-linear character of deformation: the characteristic feature for them is development of both elastic and plastic deformations. Destressing is mainly characterized by elastic deformations, while at active loading there are both elastic and plastic deformations. As during construction of the wall in the dam no new loads appear but the existing ones are redistributed, the considered problem of the structure SSS should be solved only in elastic-plastic formulation.

The fourth factor is the necessity of considering the change in an earthfill dam state at development of emergency situation in it. First of all it is necessary to take into account the appearance of the zones in the dam which were weakened as a result of soil scouring by seepage flow. This may be considered by increase of their deformation. Secondly, it is necessary to model subsidence of the structure in emergency situation.

A special calculation procedure was worked out for consideration of subsidence. It was assumed that the cause of subsidence was not just a simple disturbance of soil structure, but soil failure due to loss of part of its volume. As the remaining part of soil volume has to take forces previously applied to the whole volume, it is subject to additional deformations. However, these deformations occur in conditions of material disturbance and the ormed cavities permit free deformations of soil, full reforming of soil structure takes place. One can say that subsidence is the process of forming new soil.

Based on this in the analysis it was adopted that in subsidence zones, SSS of soil mass newly forms. All internal forces previously present in them were minimized to zero and non-balanced by them external forces formed new SSS of the structure.

Consideration of all the aforementioned peculiarities of SSS formation of the dam with a seepagecontrol wall is a rather complicated task. The first approximate solution of this problem was described in [20]. Full consideration of all the peculiarities became possible due to creation and modernization by M.P. Sainov of a special computer program NDS-N [21]. For description of elastic-plastic behavior of soil it uses the soil elastic-plastic model proposed by L.N. Rasskazov [22], and updated by M.P. Sainov.

\section{Numerical model of the structure}

SSS analysis was conducted with use of numerical modeling. A numerical model of the structure based on finite element method was developed for solving this problem. A $25 \mathrm{~m}$ high dam section with a central core of complicated configuration was considered (Fig. 1). In this section the dam is located on $20 \mathrm{~m}$ thick soil foundation presented by interlayered pebbles, clays and sands.

The dam cross section and its foundation was divided into 722 finite elements. Out of this number 679 elements modeled the behavior of continuous medium and 43 the behavior of contacts between soils and the wall clay-cement concrete (Fig. 4). At finite element discretization of the structure the use was made of high-order finite elements with cubic approximation of displacements inside the element. This permitted obtaining smooth distribution of stresses inside constructions.

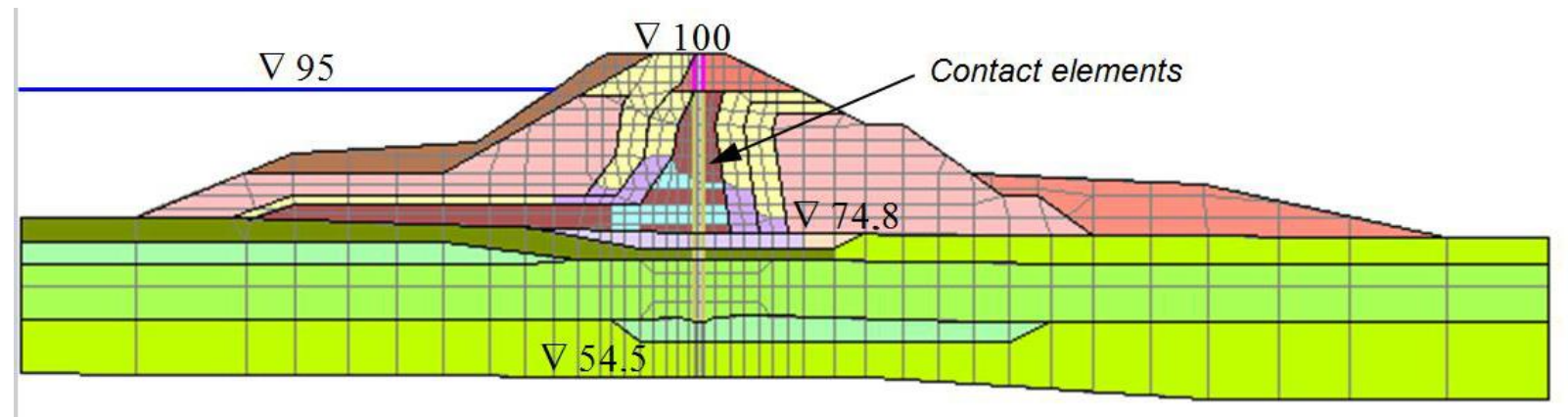

Figure 4. FEM mesh for the dam design section

Total number of degrees of freedom in the obtained numerical model amounted to 6801.

Conditions of the wall operation required considering in the structure model "the history" of its SSS formation. There were considered 26 computational steps where at each step the changes of structural

Sainov M.P., Anisimov O.V. Stress-strain state of seepage-control wall constructed for repairs of earth rock-fill dam. Magazine of Civil Engineering. 2016. No. 8. Pp. 3-17. doi: 10.5862/MCE.68.1 
design of the structure or acting on it external forces were modeled. Computational steps may be grouped in 5 characteristic stages of the structure operation.

At the first stage the foundation SSS due to its dead weight was modeled. At the second stage the computational domain SSS formation was modeled for the period of the earthfill dam construction. Gradual dam construction by horizontal layers was simulated. Twelve moments of time (steps) were modeled where at each step the dam profile rose upward. At the third stage the dam became a water retaining structure: reservoir hydrostatic pressure was applied to it. Six moments of time (steps) were considered where at each step the upstream water level gradually increased.

At the fourth computational stage the modeling was fulfilled of the structure SSS variation at appearance, development and liquidation in it of the emergency situation. At the first step of this stage the formation of water permeable zones was modeled: the character of water force action on the structure changed. Hydrostatic pressure on the core upstream face was replaced by seepage flow forces (spatially distributed seepage forces and seepage forces distributed on the surface). The second step modeled the failure itself, i.e. damage of the dam by seepage flow, when intensive seepage led to disturbance of soil structure and properties. In the structure model the zones were distinguished where soil subside and have increased deformation. They covered part of the core, transition zones as well as the sand layer in the dam foundation (Fig. 5b).
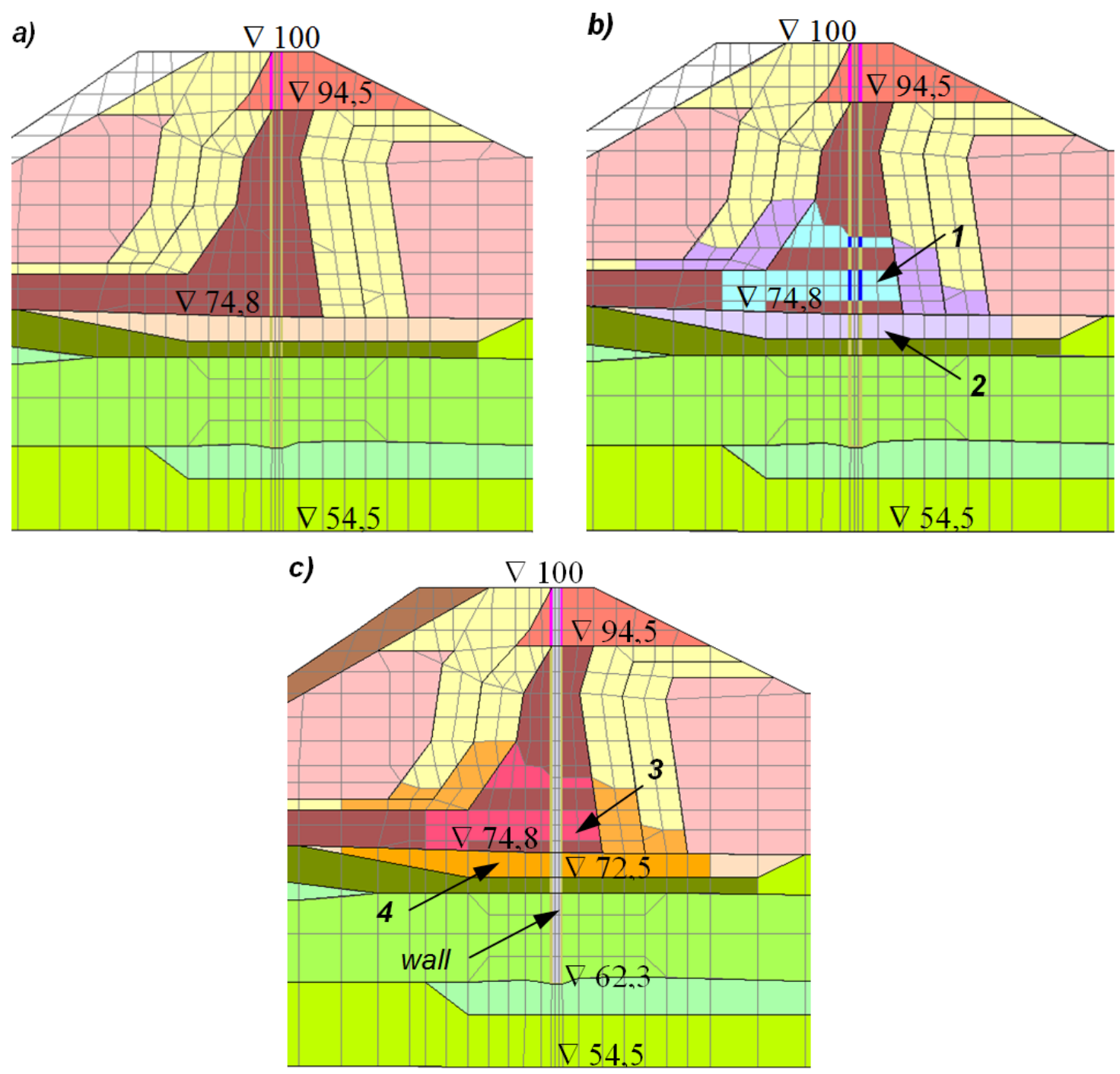

Figure 5. Changes in FEM mesh at various stages of computations (fragment) a - before failure; $b$ - during failure; $c$ - after failure, at dam construction; 1, 2 - water permeable zones and zones of subsidence, 3, 4-zones of weakened soils

At subsequent four steps of the fourth stage the emergency fill of soils on the dam slopes was modeled. On the upstream slope the clay fill was simulated, on the downstream slope the filling of filter.

Саинов М.П., Анисимов О.В. Напряженно-деформированное состояние противофильтрационной стены, выполненной для ремонта каменно-земляной плотины // Инженерно-строительный журнал. 2016. № 8(68). C. 3-17. 
The fifth stage of calculations modeled the structure operation clay-cement concrete diaphragm. This stage included computation for two time periods (steps). The first step simulated creation of the wall and its perception of its dead weight in conditions when clay-cement concrete has not yet hardened. The second step modeled perception by the wall of its external forces from filtering water. Loads on the wall were determined from solving the seepage problem. Above the dam toe the water pressure corresponded to the upstream hydrostatic pressure (Fig. 6). At computations of the second step it was assumed that by the moment of perceiving the external forces the clay-cement concrete will have already be hardened.

Deformation characteristics of soils were assumed by analogs with consideration of available data. Elastic-plastic model of soils was used.

Foundation soils were assumed to be linearly-deformed. Non-rigid characteristics of soils in soil foundation for the stage of active loading adopted in the calculation are given in Table 2.

At consideration of the dam body soils it was assumed that non-rigid characteristics depend on their stress and strength state.

Non-rigid characteristics of soils in the zones of subsidence were selected from condition of matching design dam subsidence values to field values. For soils of transition zones and the core the deformation moduli became 5 times less as compared to initial values and those of foundation sand were 6 times less.

At the stage after the failure non-rigid characteristics of soils in failure zones were taken with lower values than those which had been before the failure, because these soils have loose structure. Deformation modulus of soils was conditionally taken to be equal to half of the value which had been before the emergency situation. loading.

For all soils the deformation modulus at loosening was taken by an order more than that active

In computations the wall material was assumed to be linearly-deformed, elastic, so that it could be possible to assess its strength state. Deformation modulus of clay-cement concrete was taken equal to $200 \mathrm{MPa}$, Poisson's ratio 0.3.

For comparison the calculation was carried out where the wall material was reinforced concrete with deformation modulus $\mathrm{E}=29000 \mathrm{MPa}$ and Poisson's ratio 0.18 .

For the moment of the wall material placement into the pile in the calculation it was assumed that it had not yet hardened. Its deformation modulus was taken equal to $20 \%$ of the final value and Poisson's ratio was 0.45 .

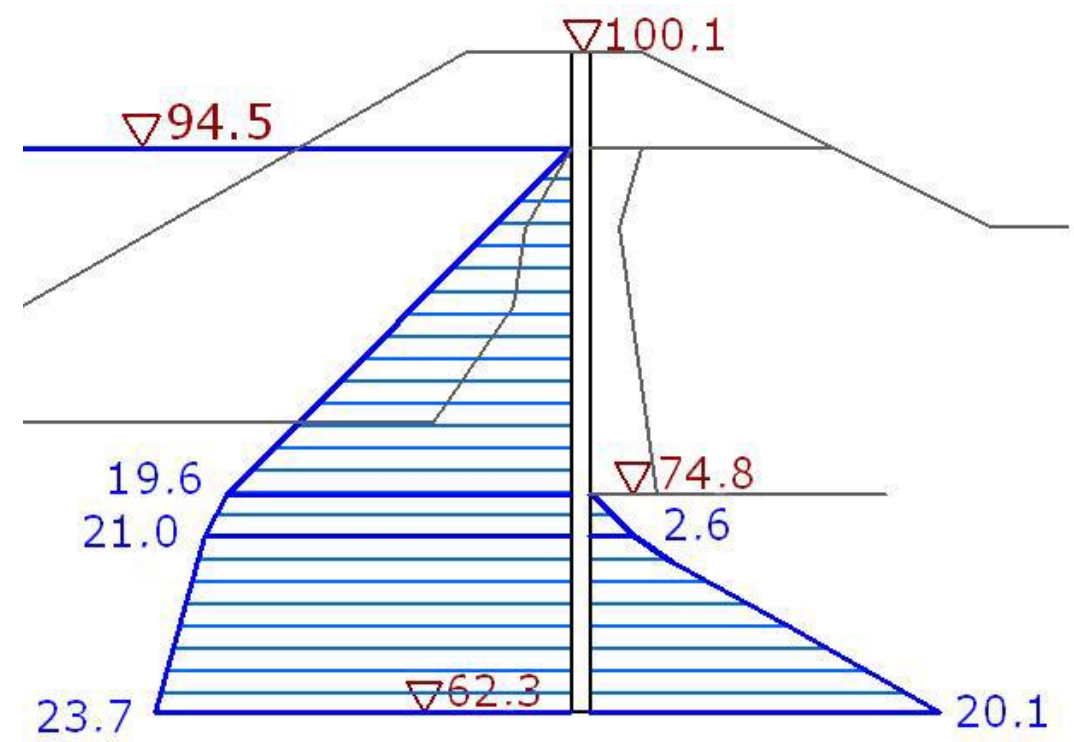

Figure 6. Design curve of seepage pressure on the pile (in $\mathrm{m}$ of water column) 
Table 2. Design non-rigid characteristics of foundation soils

\begin{tabular}{|c|c|c|}
\hline Type of soil & Deformation modulus, MPa & Poisson's ratio \\
\hline Pebble with sandy loam filler & 15 & 0.30 \\
\hline Pebble with loam filler & 15 & 0.30 \\
\hline Sandy loam & 10 & 0.40 \\
\hline Loam & 8 & 0.40 \\
\hline Sand & 6 & 0.33 \\
\hline
\end{tabular}

\section{Results and Discussion}

By the results of computations the dam has complicated SSS. Before development of emergency situation the dam SSS was considerably subject to soil foundation deformations. Under the dam dead weight and hydrostatic pressure on the apron the dam foundation settles and expands in both sides (Fig. 7, 8). The greatest settlements $(56 \mathrm{~cm})$ of foundation occurred under the apron, near the core (Fig. 8). In this zone the dam settlements also reached the maximum values $(60 \mathrm{~cm})$. The core settlements are more considerable than those of the shells.

Maximum displacements also observed on the boundary between the dam and the foundation (Fig. 7). Under the upstream shell the settlements are directed toward the upstream side (maximum $14 \mathrm{~cm}$ ). Under the downstream shell the settlements are directed toward the downstream side $(16.3 \mathrm{~cm})$. Settlements of shells in different directions may have resulted in separation of the apron from the core and development of a vertical joint at their contact.

By distribution of stresses $\sigma_{y}$ in the dam body (Fig. 10) "suspension" of the core on the shells may be noticed. In the core foundation the stresses $\sigma_{y}$ did not exceed $0.45 \mathrm{MPa}$, while in the downstream transition zone they reached $0.75 \mathrm{MPa}$. From the upstream side the core suspends weaker, because it has some inclination toward the upstream side. Deficit of compressive stresses $\sigma_{y}$ in the core could also cause failure.

By horizontal stresses $\sigma_{x}$ the core also was under compression (Fig. 9), however, their values (up to $0.2 \mathrm{MPa}$ ) were less than water pressure. At development of random cracks the disjoining hydrostatic pressure could result in hydraulic fracturing of the core especially in the zone of its contact with the apron.

At appearance in the core of water permeable zones the level of compression by stresses $\sigma_{x}$ in the upstream part of the core decreased actually to 0 . Due to hydrostatic effect of water the compressive stresses $\sigma_{y}$ also decreased.

At modeling the dam failure it was assumed that the subsidence zone covers a part of the core, both transition zones as well as the sand layer under the dam (Fig. 5b). Figures 11, 12 show design displacements of the structure at development in it of subsidence zones as a result of soil damage by seepage flow.

By the results of computations the maximum values of subsidence occurred in the upstream transition zone (Fig. 12). They amounted to $103 \mathrm{~cm}$. This may be explained by the fact that in this particular zone the soils were subject to the most intensive scour: water permeable zones appeared in the core, in the foundation sand layer, in the zone of the apron and the core conjugation (Fig. 1), besides, the transition zones were damaged. At the crest the design subsidence amounted to $95 \mathrm{~cm}$, which corresponds to the actual data [14].

The subsidence zone covered all the central part of the dam: the core and the soils surrounding it (Fig. 12). Presence of subsidence zones led to displacement of the dam crest part toward the upstream transition zone. The crest tumbles down toward the upstream side. Displacements reached $46 \mathrm{~cm}$. Vice versa, the weakened lower part of the core displaced toward the downstream side. These displacements were caused by seepage forces. Maximum displacement amounted to $19 \mathrm{~cm}$.

Саинов М.П., Анисимов О.В. Напряженно-деформированное состояние противофильтрационной стены, выполненной для ремонта каменно-земляной плотины // Инженерно-строительный журнал. 2016. № 8(68). C. 3-17. 


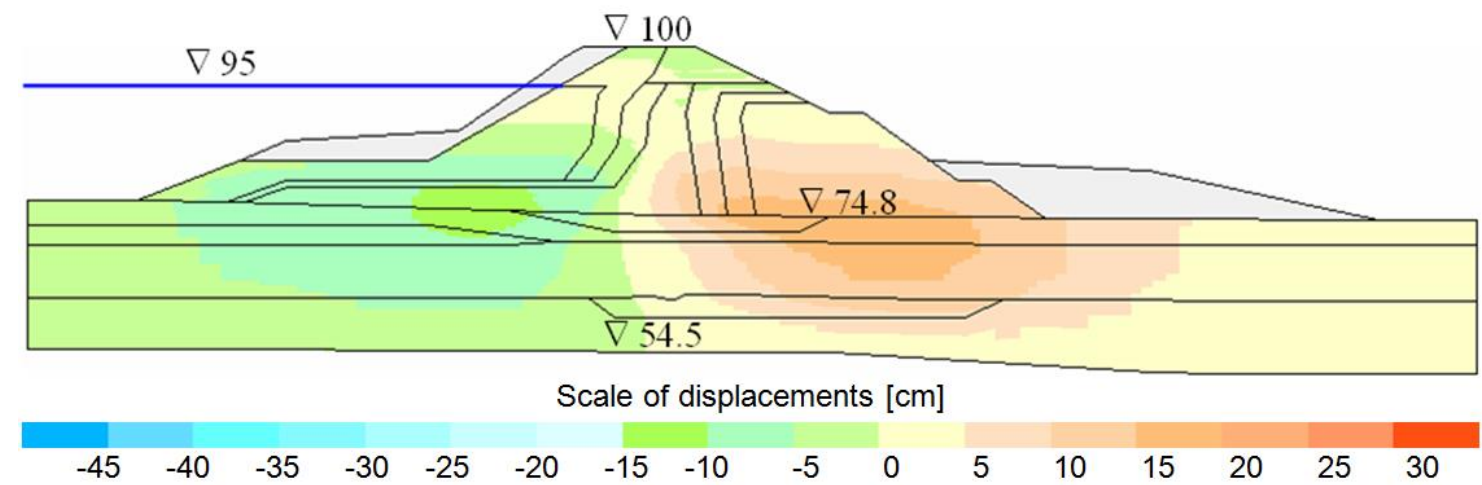

Figure 7. Structure horizontal displacements occurred during construction and reservoir filling

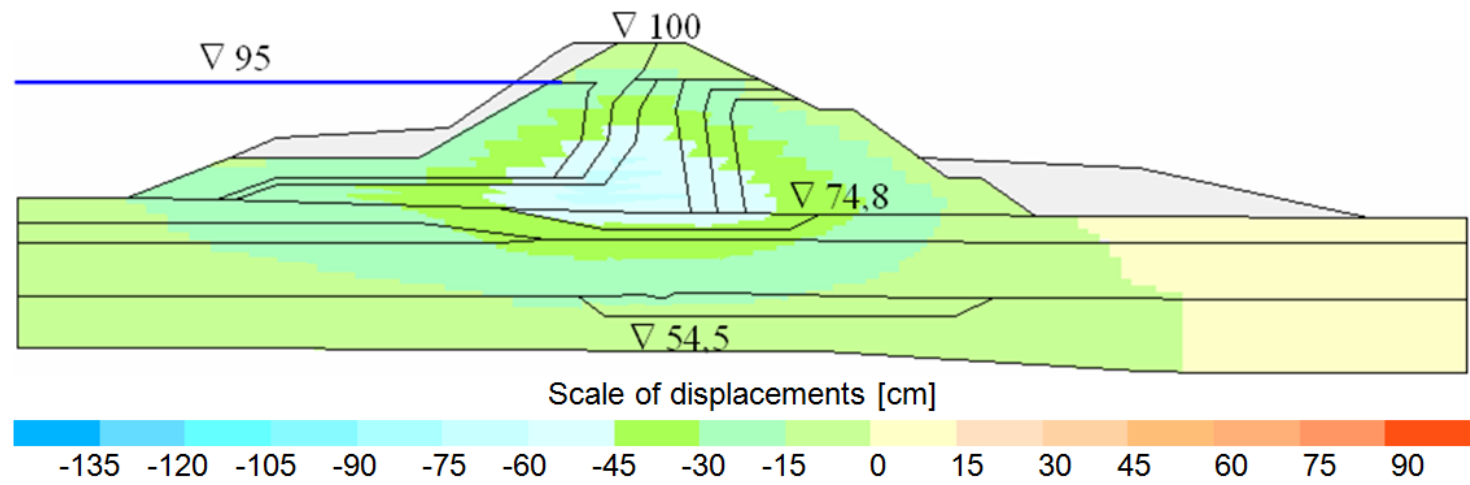

Figure 8. Structure vertical displacements occurred during construction and reservoir filling

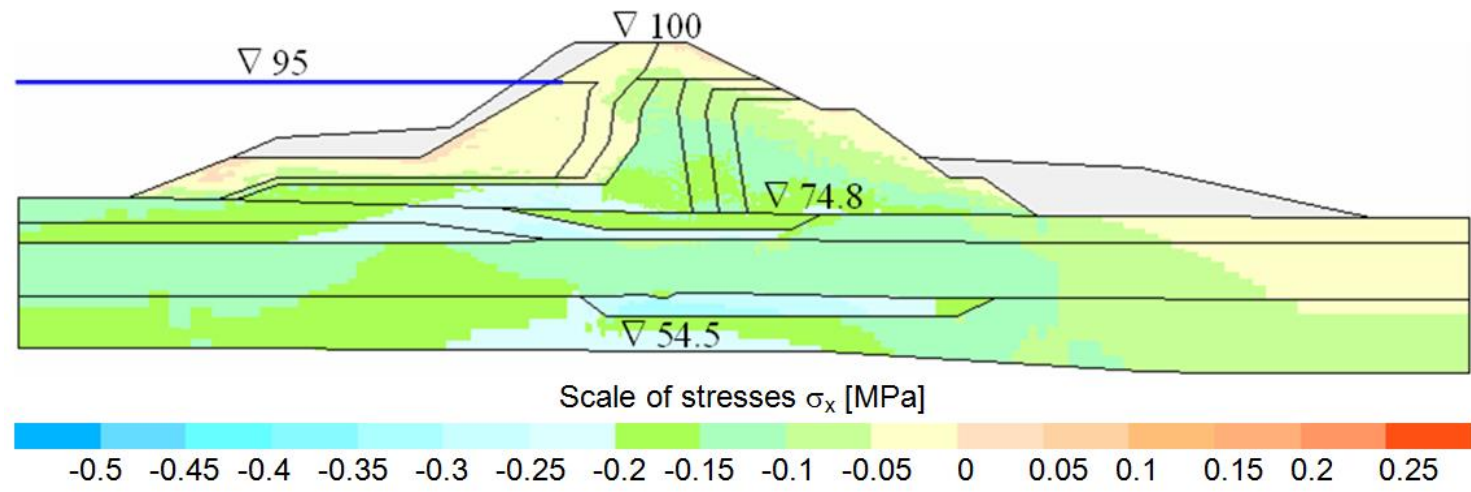

Figure 9. Horizontal stresses $\sigma \mathrm{y}$ in the dam body and foundation for the moment of construction completion and reservoir filling

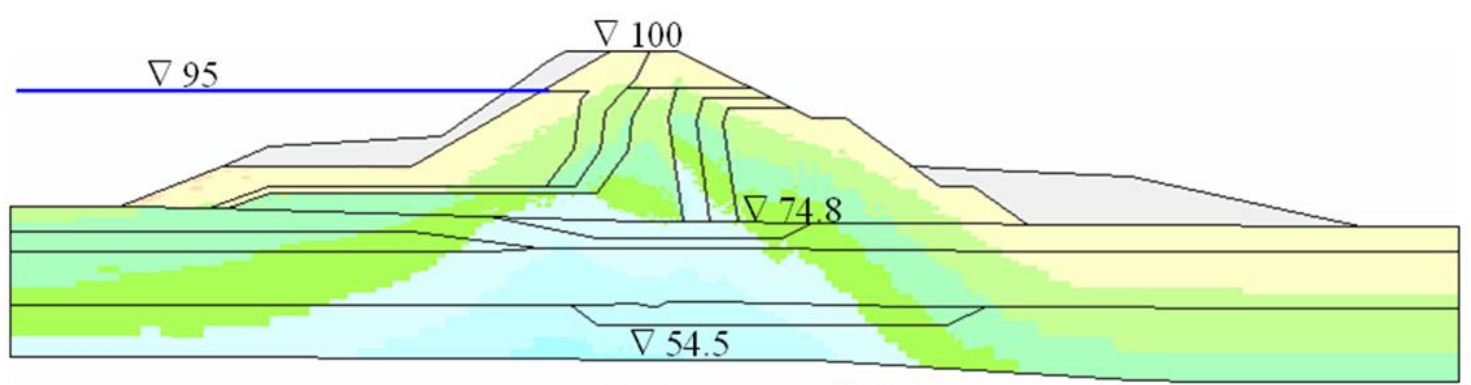

Scale of stresses $\sigma_{\mathrm{y}}[\mathrm{MPa}]$

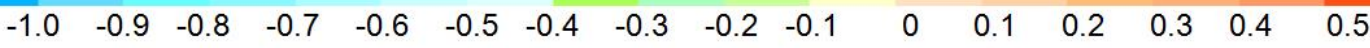

Figure 10. Vertical stresses $\sigma_{y}$ in the dam body and foundation for the moment of construction completion and reservoir filling

Sainov M.P., Anisimov O.V. Stress-strain state of seepage-control wall constructed for repairs of earth rock-fill dam. Magazine of Civil Engineering. 2016. No. 8. Pp. 3-17. doi: 10.5862/MCE.68.1 


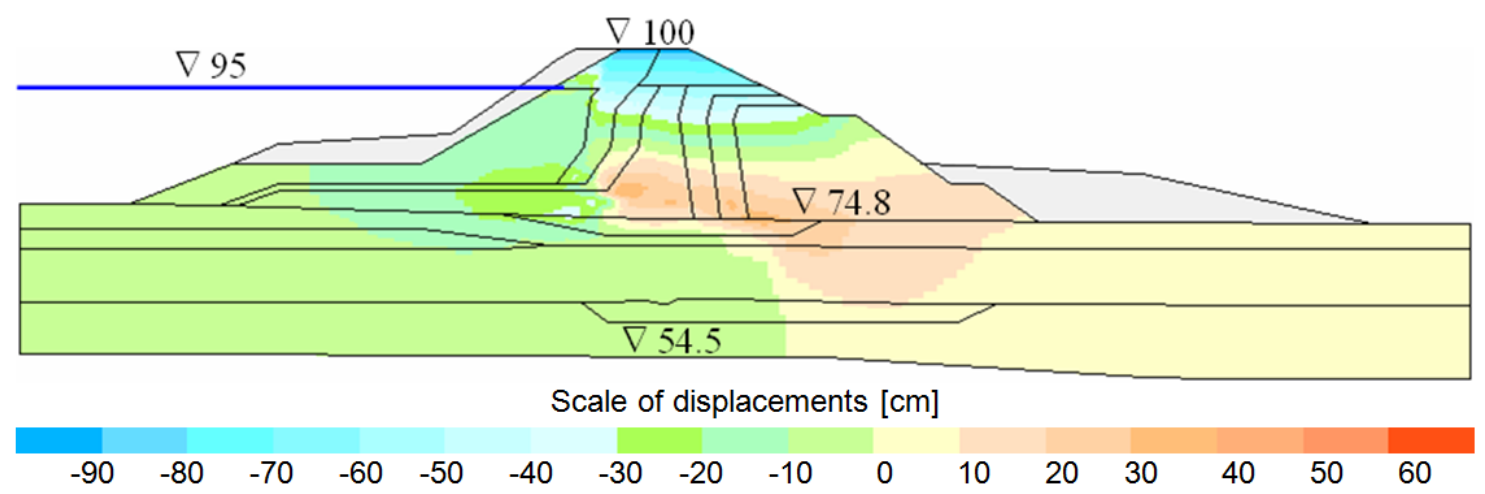

Figure 11. Structure displacements at failure development

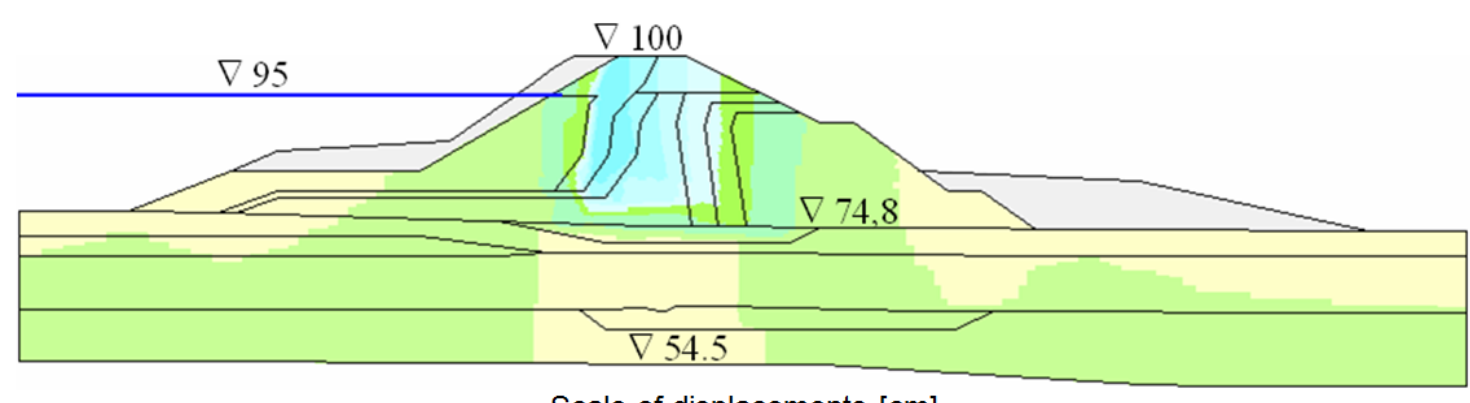

Scale of displacements $[\mathrm{cm}]$

$\begin{array}{llllllllllllllll}-135 & -120 & -105 & -90 & -75 & -60 & -45 & -30 & -15 & 0 & 15 & 30 & 45 & 60 & 75 & 90\end{array}$

Figure 12. Vertical structure displacements at failure development

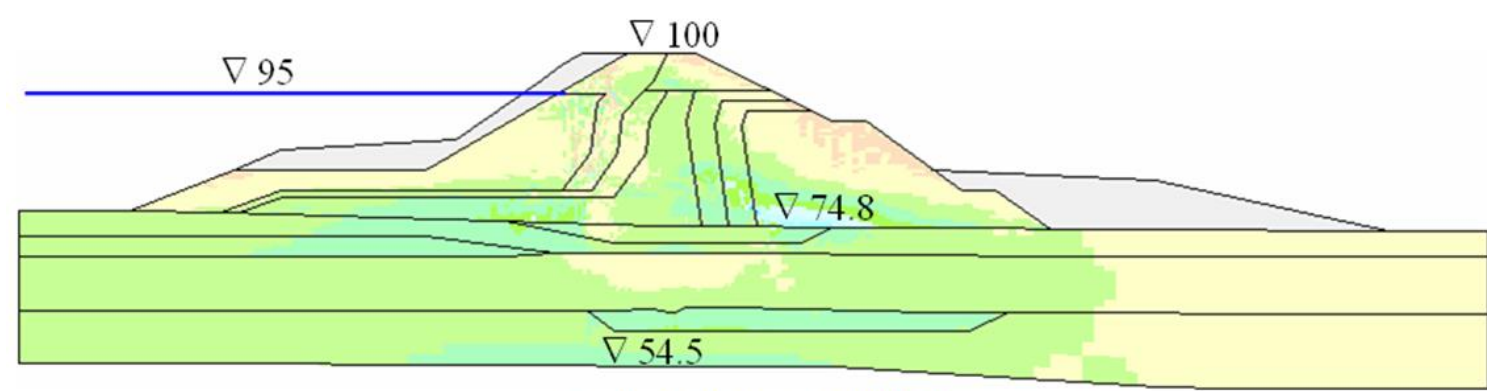

Scale of stresses $\sigma_{x}[\mathrm{MPa}]$

$\begin{array}{llllllllllllllll}-1.0 & -0.9 & -0.8 & -0.7 & -0.6 & -0.5 & -0.4 & -0.3 & -0.2 & -0.1 & 0 & 0.1 & 0.2 & 0.3 & 0.4 & 0.5\end{array}$

Figure 13. Horizontal stresses $\sigma_{y}$ in the dam body and foundation at the end of failure

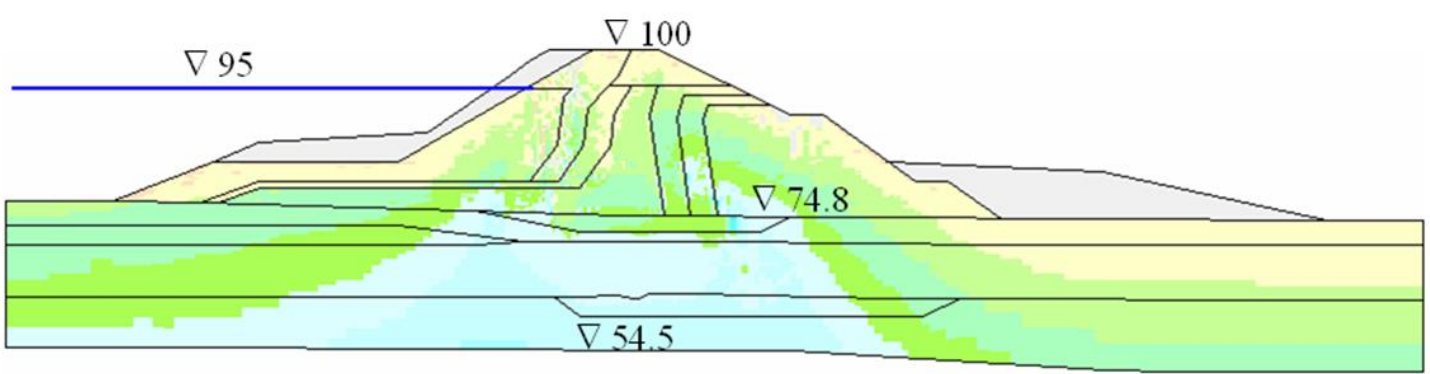

Scale of stresses $\sigma_{\mathrm{y}}[\mathrm{MPa}]$

$\begin{array}{llllllllllllllll}-1.0 & -0.9 & -0.8 & -0.7 & -0.6 & -0.5 & -0.4 & -0.3 & -0.2 & -0.1 & 0 & 0.1 & 0.2 & 0.3 & 0.4 & 0.5\end{array}$

Figure 14. Vertical stresses $\sigma_{\mathrm{y}}$ in the dam body and foundation at the end of failure

Саинов М.П., Анисимов О.В. Напряженно-деформированное состояние противофильтрационной стены, выполненной для ремонта каменно-земляной плотины // Инженерно-строительный журнал. 2016. № 8(68). C. $3-17$. 
Loss by the dam central part of its load bearing capacity resulted in redistribution of stresses in the dam (Figs. 13, 14). The shells took larger vertical loads; stresses $\sigma_{y}$ in them increased sharply (Fig. 14). Vice versa, stresses $\sigma_{y}$ in the foundation under the core considerably decreased.

The level of compression in the downstream shell sharply increased also by stresses $\sigma_{x}$ (Fig. 13). The maximum value of stresses $\sigma_{x}$ amounted to $0.9 \mathrm{MPa}$. This is connected with transfer of the core lower part loads to it. By the results of computations, in the upper part of the downstream shell the vertical spalled joints appeared, which corresponds to the field data [14].

At arrangement of the seepage-control wall the structure SSS slightly changed. Increments in displacements and stresses in the dam body turned to be small. This is connected with the fact that the wall accumulated only those horizontal loads which the dam had already taken earlier.

The wall displacement curves are shown in Figures 15, 16. The wall displacement curve has an irregular shape. Its maximum is in the core lower part, weakened by scour, i.e. approximately in the middle of the wall height. The clay-cement concrete wall maximum displacement amounted to $10.1 \mathrm{~cm}$. The wall top and bottom have less displacement: not exceeding $7 \mathrm{~cm}$.

At constructing the reinforced concrete wall the wall displacements become more smooth (Fig. 16), but generally the wall follows soil deformations. The reinforced concrete wall maximum displacement amounted to $7.9 \mathrm{~cm}$.

The shape of displacement curve evidences about the wall complicated bending deformations. Apart from the main bend in maximum displacements the curve also has local bends in the zones of contact with soils of various properties. In the zone of maximum displacement the wall bend toward the downstream side.

The wall bend results in irregular distribution of vertical stresses $\sigma_{y}$ in it. The most dangerous part of the wall is in the zone of maximum bends. In this part the compression level on the upstream face increases, on the downstream face it decreases. There are two more such sections. All these sections are confined to failure zones in the core and in the foundation. At the section between the failure zones the bend tends to the upstream side, therefore, compression occurs on the upstream face.

When the wall is made of clay-cement concrete the impact of bend deformations on values of stresses $\sigma_{y}$ is weak (Fig. 15): no tensile stresses in the wall occur.

In the wall made of reinforced concrete the characteristic feature is appearance of considerable tensile stresses (Fig. 16). They are many times more than concrete tensile strength. That is why it is desirable to use the material with low deformation modulus in order to avoid cracking in the wall.

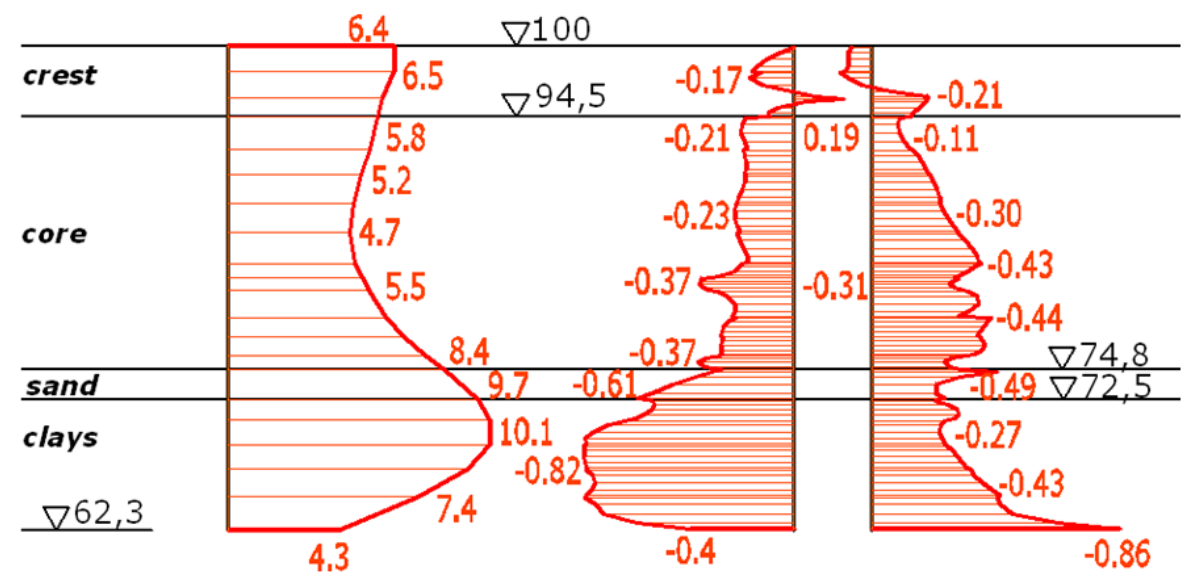

a)

b) c)

Figure 15. Stress-strain state of clay-cement concrete wall: a - horizontal displacements from seepage forces; b - vertical stresses $\sigma y$ on the upstream face; c - vertical stresses $\sigma y$ on the downstream face 


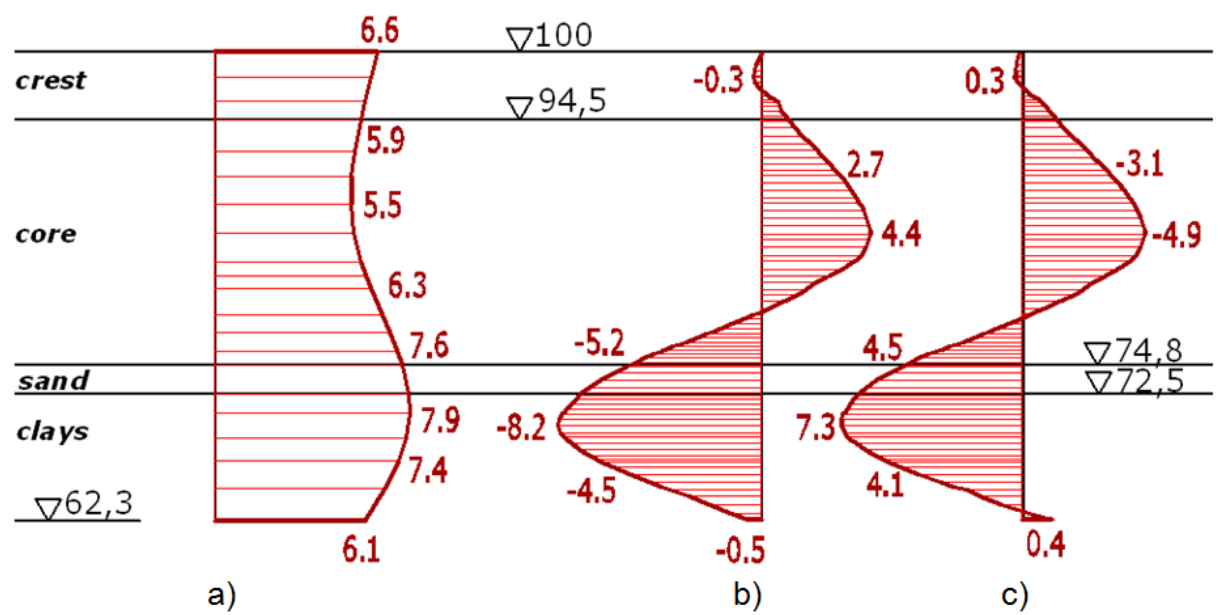

Figure 16. Stress-strain state of concrete wall:

$a$ - horizontal displacements from seepage forces; $b$ - vertical stresses $\sigma_{y}$ on the upstream face; $c$ - vertical stresses $\sigma_{y}$ on the downstream face

The greatest compressive stresses $\sigma_{y}$ appear on the wall foot (Fig.15). These stresses are less than clay-cement concrete compressive strength, which amounts to 1-2 MPa $[18,19]$. There is no danger of compressive strength failure.

\section{Conclusions}

1. The problem of stress-strain state of the wall constructed as a new seepage-control element of failed earhfill dam has a number of peculiarities which complicates its solution. The result of solution to a great extent depends on consideration of these peculiarities, adequacy of the structure design scheme. At computations it is necessary to take into account:

- Dam SSS peculiar features before construction of the wall in it,

- Process diagram of the wall construction by method of the «cutoff wall»,

- Variation of loads on the structure from seepage flow,

- Presence of failure zones and soil subsidence in the dam,

- Elastic-plastic character of soils deformation.

2. Solving the problem of the seepage-control wall SSS in a failed eathfill dam requires solving the seepage problem for determining seepage loads on the structure. Due to the fact that construction of the wall with separate bored piles is a rather durable process, seepage load on the wall forms durable time. It may be also assumed that the wall will perceive seepage forces when clay-cement concrete is already hardened.

3. The peculiar feature of seepage-control wall operation on failed eartfill dam is the fact that earlier the dam had already perceived horizontal loads and was adapted to their perception. Therefore, horizontal wall displacements due to seepage load are not large. This is favorable for safety of the wall as a seepage-control element.

4. The main unfavorable factor complicating operation conditions of the seepage-control wall in the failed dam is the fact that the soil mass surrounding it has heterogeneous structure and may contain soil zones with disturbed structure and low strength. Therefore, at perceiving horizontal forces the dam is subject to complicated bending deformations which may worsen its tensile or compressive strength.

5. For material of the seepage-control wall in the failed dam it is recommended to use plastic claycement concrete, which by deformability is close to the surrounding soil mass with secant modulus of deformation not exceeding $300 \mathrm{MPa}$. This permits avoiding appearance of tensile stresses in the wall. Compressive stresses in the wall will not exceed the clay-cement concrete compressive strength.

6. At solving the considered problem we worked out and used the method accounting at structures SSS calculations of subsidence of soils subject to scour by seepage flow.

Саинов М.П., Анисимов О.В. Напряженно-деформированное состояние противофильтрационной стены, выполненной для ремонта каменно-земляной плотины // Инженерно-строительный журнал. 2016. № 8(68). C. $3-17$. 


\section{References}

1. Baranov A.Ye. Iz opyta proyektirovaniya i stroitelstva Yumaguzinskogo gidrouzla na r. Beloy [From the experience of design and construction of the Yumaguzinsky hydroelectric complex on the river Belaya]. Vestnik MGSU. 2006. No. 2. Pp. 112-122. (rus)

2. Tsoy M.S.-D., Aldanov A.G., Radchenko V.G., Semenov Yu.D., Danilov A.S., Smolenkov V.Yu. Vozvedeniye protivofiltratsionnoy zavesy metodom struynoy tsementatsii v osnovanii plotiny Sangtudinskoy GES-1 [The erection of the anti-filtration curtain by the method of jet grouting in the base of the dam of Sangtudinskaya HPP-1] Gidrotekhnicheskoye stroitelstvo. 2008. No. 5. Pp. 32-37. (rus)

3. Mirghasemi A.A., Pakzad M., Shadravan B. The world's largest cutoff wall at Karkheh dam. Hydropower \& Dams. 2005. No. 2. Pp. 2-6.

4. Ehrhardt T., Scheid Y., El Tayeb A. Entwurf und ausfuhrung der steinschuttdamme und der schlitzwand des MeroweProjektes. WasserWirtschaft. 2011. No. 101(1-2). Pp. 3642

5. Balian S. Cut-off wall construction. International Water Power and Dam Construction. 2007. No. 59(2). Pp. 42-44.

6. Brown A.J., Bruggemann D.A. Arminou Dam, Cyprus, and construction joints in diaphragm cut-off walls. Geotechnique. 2002. Vol. 52. No. 1. Pp. 3-13.

7. Brunner W.G. The first cut-off wall in the Indian Himalayas for the dam of the Dhauliganga hydroelectric project. Source Dam Safety. 2007.

8. Amos P.D., Bruce D.A., Lucchi M., Newson T., Wharmby N Design and construction of seepage cut-off walls under a concrete dam in New Zealand with a full reservoir. Source of the Document Association of State Dam Safety Officials Dam Safety. 2007

9. Demars B., Pledger C., Barrett, B. A.V. Watkins dam modification: cement-bentonite slurry cutoff wall. Proc. 29th

10. Radchenko V.G., Lopatina M.G., Nikolaychuk Ye.V., Radchenko S.V. Opyt vozvedeniya protivofiltratsionnykh ustroystv iz gruntotsementnykh smesey [Experience in erection of anti-filtration devices from ground-cement mixtures]. Gidrotekhnicheskoye stroitelstvo. 2012. No. 12 Pp. 46-54. (rus)

11. Noll H., Langhagen K., Popp M., Lang T. Ertuchtigung des Sylvenstein-Staudamms - Planung und Ausfuhrung der Dichtwand. WasserWirtschaft. 2013. Vol. 103. No. 5 Pp. 76-79.

12. Vaughan P.R., Kluth D.J., Leonard M.W., Pradoura H.H.M. Cracking and erosion of the rolled clay core of Balderhead dam and the remedial works adopted for its repair. 1970. 10th ICOLD Congress. No. 1. Pp. 73-93.

13. $\mathrm{Ng}$ A.K.L., Small J.C. A case study of hydraulic fracturing using finite element methods. A case study of hydraulic Geotechnical Journal. 1999. Vol. 36. No. 5. Pp. 861-875.

14. Myznikov Yu.N. Konstruktivno-tekhnologicheskiye resheniya, obespechivayushchiye nadezhnost gruntovykh plotin na Kraynem Severe [Structural and technological solutions ensuring the reliability of ground dams in the Far North]. Gidrotekhnicheskoye stroitelstvo. 1993. No. 12 Pp. 33-38. (rus)

15. Malyshev L.I., Rasskazov L.N., Soldatov P.V. Sostoyaniye plotiny Kureyskoy GES i tekhnologicheskiye resheniya po yeye remontu [The condition of the dam of the Kureyskaya HPP and technological solutions for its repair]. Gidrotekhnicheskoye stroitelstvo. 1999. No. 1. Pp. 31-36. (rus)

16. Pekhtin V.A., Serov V.A., Susloparov V.A. O konstruktsii grebney kamenno-zemlyanykh plotin $v$ severnoy stroitelnoklimaticheskoy zone [On the design of the crests of rock and of the Document Association of State Dam Safety Officials USSD Conference. 2009 fracturing using finite element methods. Canadian

\section{Литература}

1. Баранов А.Е. Из опыта проектирования и строительства Юмагузинского гидроузла на р. Белой // Вестник МГСУ. 2006. № 2. С. 112-122

2. Цой М.С.-Д., Алданов А.Г., Радченко В.Г., Семёнов Ю.Д., Данилов А.С., Смоленков В.Ю. Возведение противофильтрационной завесы методом струйной цементации в основании плотины Сангтудинской ГЭС-1 // Гидротехническое строительство. 2008. № 5. С. 3237

3. Mirghasemi A.A., Pakzad M., Shadravan B. The world's largest cutoff wall at Karkheh dam // Hydropower \& Dams. 2005. № 2. Pp. 2-6.

4. Ehrhardt T., Scheid Y., El Tayeb A. Entwurf und ausfuhrung der steinschuttdamme und der schlitzwand des Merowe-Projektes // WasserWirtschaft. 2011. № 1-2(101). Pp. 36-42.

5. Balian S. Cut-off wall construction // International Water Power and Dam Construction. 2007. № 2(59). Pp. 42-44.

6. Brown A.J., Bruggemann D.A. Arminou Dam, Cyprus, and construction joints in diaphragm cut-off walls // Geotechnique. 2002. Vol. 52. № 1. Pp. 3-13.

7. Brunner W.G. The first cut-off wall in the Indian Himalayas for the dam of the Dhauliganga hydroelectric project // Source of the Document Association of State Dam Safety Officials - Dam Safety. 2007.

8. Amos P.D., Bruce D.A., Lucchi M., Newson T., Wharmby N. Design and construction of seepage cut-off walls under a concrete dam in New Zealand with a full reservoir // Source of the Document Association of State Dam Safety Officials - Dam Safety. 2007

9. Demars B., Pledger C., Barrett B. A.V. Watkins dam modification: cement-bentonite slurry cutoff wall // Proc. 29th USSD Conference. 2009.

10. Радченко В.Г., Лопатина М.Г., Николайчук Е.В., Радченко С.В. Опыт возведения противофильтрационных устройств из грунтоцементных смесей // Гидротехническое строительство. 2012. № 12. С. 46-54.

11. Noll H., Langhagen K., Popp M., Lang T. Ertuchtigung des Sylvenstein-Staudamms - Planung und Ausfuhrung der Dichtwand // WasserWirtschaft. 2013. Vol. 103. № 5. Pp. 76-79.

12. Vaughan P.R., Kluth D.J., Leonard M.W., Pradoura H.H.M. Cracking and erosion of the rolled clay core of Balderhead dam and the remedial works adopted for its repair // 10th ICOLD Congress. 1970. № 1. Pp. 73-93.

13. Ng A.K.L., Small J.C. A case study of hydraulic fracturing using finite element methods. A case study of hydraulic fracturing using finite element methods // Canadian Geotechnical Journal. 1999. Vol. 36. № 5. Pp. 861-875.

14. Мызников Ю.Н. Конструктивно-технологические решения, обеспечивающие надежность грунтовых плотин на Крайнем Севере // Гидротехническое строительство. 1993. № 12. С. 33-38.

15. Малышев Л.И., Рассказов Л.Н., Солдатов П.В Состояние плотины Курейской ГЭС и технологические решения по её ремонту // Гидротехническое строительство. 1999. № 1. С. 31-36.

16. Пехтин В.А., Серов В.А., Суслопаров В.А. О конструкции гребней каменно-земляных плотин В северной строительно-климатической зоне // Гидротехническое строительство. 1998. № 3. С. 36-40.

17. Бардюков В.Т., Изотов В.Н., Гришин В.А., Радченко В.Г., Шишов И.Н. Ремонт плотины Курейской ГЭС // Известия Всероссийского научно-исследовательского института гидротехники им. Б.Е. Веденеева. 2000. Т. 238. С. 9296.

18. Малышев Л.И., Шишов И.Н., Кудрин К.П., Бардюков В.Г. Технические решения и результаты первоочередных работ по сооружению противофильтрационной стены в

Sainov M.P., Anisimov O.V. Stress-strain state of seepage-control wall constructed for repairs of earth rock-fill dam. Magazine of Civil Engineering. 2016. No. 8. Pp. 3-17. doi: 10.5862/MCE.68.1 
earth dams in the northern construction and climatic zone]. Gidrotekhnicheskoye stroitelstvo. 1998. No. 3. Pp. 36-40. (rus)

17. Bardyukov V.T., Izotov V.N., Grishin V.A., Radchenko V.G., Shishov I.N. Remont plotiny Kureyskoy GES [Repair of the Kureyskaya HPP]. Izvestiya Vserossiyskogo nauchnoissledovatelskogo instituta gidrotekhniki im. B.Ye. Vedeneyeva. 2000. Vol. 238. Pp. 92-96. (rus)

18. Malyshev L.I., Shishov I.N., Kudrin K.P., Bardyukov V.G. Tekhnicheskiye resheniya i rezultaty pervoocherednykh rabot po sooruzheniyu protivofiltratsionnoy steny $v$ grunte $v$ yadre i osnovanii plotiny Kureyskoy GES [Technical solutions and results of priority works on the construction of an anti-filtration wall in the ground in the core and the foundation of the Kureyskaya HPP dam]. Gidrotekhnicheskoye stroitelstvo. 2001. No. 3. Pp. 31-36. (rus)

19. Grishin, V.A., Deryugin, L.M. Experience in the use of bentonite-cement concrete for repairing the core of the earthfill dam of Kureiskaya HPP. Power Technology and Engineering. 2006. Vol. 40. No. 2. Pp. 90-95.

20. Rasskazov L.N., Bestuzheva A.S., Sainov M.P. Betonnaya diafragma kak element rekonstruktsii gruntovoy plotiny [Concrete diaphragm as an element of the reconstruction of the earth dam]. Gidrotekhnicheskoye stroitelstvo. 1999. No. 4. Pp. 10-16. (rus)

21. Sainov M.P. Vychislitelnaya programma po raschetu napryazhenno-deformirovannogo sostoyaniya gruntovykh plotin: opyt sozdaniya, metodiki i algoritmy [Computational program for calculating of the ground dams stress-strain state: creation experience, methods and algorithms]. International Journal for Computational Civil and Structural Engineering. 2013. No. 9(4). Pp. 208-225. (rus)

22. Rasskazov L.N., Dzhkha Dzh. Deformiruyemost i prochnost grunta pri raschete vysokikh gruntovykh plotin [Deformability and strength of soil in the calculation of high ground dams]. Gidrotekhnicheskoye stroitelstvo. 1987. No. 7. Pp. 31-36. (rus)

Mikhail Sainov,

+7(926)6078931; mp_sainov@mail.ru

Oleg Anisimov,

+7(926)3366690; anisimov.apple@gmail.com грунте в ядре и основании плотины Курейской ГЭС // Гидротехническое строительство. 2001. № 3. С. 31-36.

19. Grishin, V.A., Deryugin, L.M. Experience in the use of bentonite-cement concrete for repairing the core of the earthfill dam of Kureiskaya HPP // Power Technology and Engineering. 2006. Vol. 40. № 2. Pp. 90-95.

20. Рассказов Л.Н., Бестужева А.С., Саинов М.П. Бетонная диафрагма как элемент реконструкции грунтовой плотины // Гидротехническое строительство. 1999. № 4. C. $10-16$.

21. Саинов М.П. Вычислительная программа по расчёту напряжённо-деформированного состояния грунтовых плотин: опыт создания, методики и алгоритмы // International Journal for Computational Civil and Structural Engineering. 2013. № 9(4). Pp. 208-225.

22. Рассказов Л.Н., Джха Дж. Деформируемость и прочность грунта при расчете высоких грунтовых плотин // Гидротехническое строительство. 1987. № 7. C. $31-36$.
Михаил Петрович Саинов, +7(926)6078931; эл. почma: mp_sainov@mail.ru

Олег Владимирович Анисимов, +7(926)3366690; эл. почта: anisimov.apple@gmail.com

(C) Sainov M.P., Anisimov O.V., 2016

Саинов М.П., Анисимов О.В. Напряженно-деформированное состояние противофильтрационной стены, выполненной для ремонта каменно-земляной плотины // Инженерно-строительный журнал. 2016. № 8(68). C. 3-17. 